\title{
Gendered interests and poor spousal contraceptive communication in Islamic northern Nigeria
}

\author{
Chimaraoke Izugbara, Latifat Ibisomi, Alex C Ezeh, Mairo Mandara
}

\begin{abstract}
Relying on focus group discussions and in-depth individual interviews with men and women in Jigawa and Kano states in northern Nigeria, we investigated barriers to spousal contraceptive communication. While attitudes toward spousal contraceptive communication were generally positive, there was very little evidence that respondents engaged in it. Poor spousal contraceptive communication in northern Nigeria is, in many ways, driven by the ample incentives that husbands and wives have to keep having children. For wives, having many children stabilises their marriage. It prevents husbands from marrying additional wives and sustains their attention and investments even if they ultimately do. For husbands, having many children helps them to keep their wives from
\end{abstract}

objecting to their taking other wives and to mollify them by showing their continued commitment to that relationship should they take other wives. Our findings clearly challenge conventional population, family planning and reproductive health programmes that view high fertility as disempowering for women, and contraceptive use as capable of redressing gender inequality. New norms of gender relations are key to promoting contraceptive uptake and smaller families in northern Nigeria.

Keywords gendered interests, men, northern Nigeria, spousal contraceptive communication, women

J Fam Plann Reprod Health Care 2010; 36(4): 219-224

(Accepted 25 February 2010)

\section{Introduction}

Northern Nigeria is characterised by very high fertility and low use of modern contraceptive methods. Currently, total fertility (TF) and contraceptive use rates in the region stand at 6.5 and 6.4, respectively, contrasting sharply with rates of 4.3 and 23.7 in southern Nigeria.1,2 Poor spousal contraceptive communication has been identified as a key driver of low uptake of family planning services in northern Nigeria, ${ }^{2-5}$ with current evidence suggesting that northern Nigerian couples rarely discuss matters concerning family planning and contraception together. ${ }^{1}$ Yet as Rakhshani et al. ${ }^{6}$ suggest, fertility-related communication enables spouses to discern each other's attitudes toward family planning and use of contraception. It promotes shared decision-making and helps partners ventilate their concerns about reproductive health matters, including sexually transmitted infections and unwanted pregnancies.

Judging by more recent studies, support for family planning and contraceptive use is not only rising among women and men in northern Nigeria, but they also express very favourable attitudes toward fertility-related spousal communication. $3,7,8$ So, why then is spousal contraceptive communication rare in northern Nigeria and particularly why are husbands and wives, many of whom assert no disinclination toward spousal contraceptive discussion, ultimately unable to initiate it? The present study responds to these questions by building particularly on the growing body of social scientific scholarship which posits fertility as a site of conflicts and negotiations and as a critical political resource; ${ }^{9-13}$ which recognises negotiations and tussles over fertility as mirroring the strategic interests of

African Population \& Health Research Center, Nairobi, Kenya Chimaraoke Izugbara, PhD, Research Scientist

Latifat Ibisomi, PhD, Postdoctoral Fellow

Alex C Ezeh, PhD, Executive Director

Packard Foundation, Garki, Abuja, Nigeria

Mairo Mandara, MD, Senior Country Advisor

Correspondence to: Dr Chimaraoke Izugbara, African Population \& Health Research Center, 2nd Floor, Shelter Afrique Center, Longonot Road, Box 10787, Upper Hill, Nairobi 00100, Kenya.

E-mail: cizugbara@aphrc.org or coizugbara@yahoo.com

\section{Key message points}

- Although husbands and wives in Islamic northern Nigeria assert no disinclination toward spousal contraceptive communication, it remains rare in the region.

- Poor spousal communication in Islamic northern Nigeria is related to the gendered incentives that the region's men and women have to keep having children.

- In order to promote contraceptive communication in the region, new norms of gender relations are needed.

individuals, couples and societies:11,14-16 and which holds that marital fertility is influenced by both the micro-politics of gender and marriage as well as by macro-level issues which surround couples. ${ }^{11,16,17}$

We argue in this article that the extent to which northern Nigerian women make efforts to suggest contraception to their husbands is fundamentally limited among other things, by their anxieties about having co-wives, their worries about being divorced, and their concerns about losing their husbands' goodwill, favour and support. On the other hand, men's silence regarding family planning is not only related to their apprehension with the dire consequences of being considered unjust by their wives, it is also strategic to assuring wives of their commitment, which helps the men to accomplish other motives including marrying new wives. We suggest further that poor spousal contraceptive communication in northern Nigeria is, by and large, the by-product of the opportunities, or lack of them, which men and women have within marital unions in which fertility is a crucial factor. The emerging evidence is critical for social and policy action aiming to improve the uptake of family planning in northern Nigeria. Efforts to support women's access to contraception in northern Nigeria will need to be matched by the creation of new social norms of gender and economic opportunities. ${ }^{11}$

\section{Methods}

\section{Tools and design}

In-depth individual interviews (IDIs) and focus group discussions (FGDs) provided data for this study. These were implemented between December 2007 and August 2008 in Jigawa and Kano states in northern Nigeria as part 
of a study to understand the factors motivating and demotivating women to space or limit their childbearing. In each state, three communities (one rural, one urban and one semi-urban) were selected through a multistage sampling process that initially involved the random selection of three local government areas (LGAs) in each state. From the most urbanised of the sample LGAs, we purposively selected an urban community; from the second most urbanised; a semi-rural community; and from the least urbanised, a rural community. In each setting, nine female and four male FGDs, and 13 and four IDIs were conducted.

The recruitment of respondents was also largely purposive, often with the aid of key informants, mainly staff of local non-governmental organisations, health and family planning services providers, and community leaders from the specific study sites. The role of key informants included identifying women and men in their communities with sundry fertility and contraceptive experiences, different marriage backgrounds, and from a variety of reproductive ages; explaining the research objectives to them; and soliciting for their participation. Key informants thus provided the dual advantage of being able to make proper arrangements for introductions and contacts with the participants as well as volunteering insights into the study participants' world and social contexts of which they are a part. In focusing on men and women with varied reproductive and other fertility-related experiences, we sought to understand the sociocultural and economic issues and processes surrounding spousal discussions on contraception in northern Nigeria. Male key informants recruited male respondents and female key informants, female respondents. Respondents for the IDIs were drawn from the focus group participants. In-depth interviews sought to investigate issues already addressed at the group interview level, and to especially educe more information relating to personal experiences, which may not surface in FGDs. Interviews were conducted mainly in Hausa language, the local language of the respondents, by male and female field workers who were trained to be able to promptly establish rapport and to elicit interviews without causing embarrassment and resentment among the respondents.

\section{Ethical approval}

In addition to ethical clearance granted us by the Research and Documentation Unit of Kano State, Nigeria, we also sought and received research approval from the ministries of local governments of both Kano and Jigawa states. All participants also verbally consented to the audio recording of their responses and were guaranteed anonymity and confidentiality of their responses.

\section{Data analysis}

The interviews generated a copious amount of qualitative data on several issues related to fertility, family size, contraception and marriage. The taped data were transcribed by professionals, under the technical supervision of two Hausa language teachers at the Bayero University, Kano State and four ranking journalists from local media outfits in the two states. The data were thoroughly anonymised and pseudonyms are used in this article. We achieved immersion in the data ${ }^{18}$ by reading the transcribed texts over and over again and developing memos based on issues arising from the transcripts. Data analysis involved thematic content examination of the memos, using in vivo coding strategy and the continual investigation of the themes for categories, linkages and properties. In many instances, we used verbatim quotations to illustrate responses on relevant issues and themes. Following Dobrzykowki and Stern ${ }^{19}$ we compared our analysis with what other authors had written on the issues addressed by the study. Colleagues and collaborators were also shown drafts of our analysis to see if they rang true.

\section{Study limitations}

A key drawback of the present study is that it does not specifically match the views of couples. Juxtaposing the views and beliefs of spouses on spousal communication would have yielded more critical insights on the issue. It is also difficult to say how the recruitment strategy influenced the findings. Further, the data used here are primarily qualitative, derived from individual interviews and FGDs. They are not backed by participant observations, creating a certain ethnographic slenderness that reflects what people say about their lives as opposed to actual long-term observations of behaviour and social life. Yet, as with most qualitative research, this study can claim the generation of in-depth and new scientific insights and information about the sample under observation. ${ }^{20}$

\section{Results}

\section{Study participants}

Study participants were ever-married men and women, ranging in age from 14 to 81 years (average age 43 years). Responding women were slightly younger, averaging 37 years. Respondents largely self-identified as Muslims. Only a handful of Animists and Christians were in the sample. The bulk of the respondents had no formal education. Mean years of completed formal schooling was very low (approximately 2.5 years). Respondents reporting secondary and higher level of education were mainly men. Reports of completing traditional Koranic schools or makaranta allo and Islamiyyah schools were very common among both male and women participants. At the time of the study, $64 \%$ of the men and women in the study were in polygamous marriages. The Population Council ${ }^{21}$ shows that polygyny is normative in northern Nigeria and that the prevalence of polygyny in the region is among the highest globally. Participating women had an average family size of seven and owing largely to pervasive polygyny, the comparative figure for men was 12 . Interlocutors selfreported largely as farmers, petty traders, business folk and labourers. A few participants, especially the men, were also employees of government and other formal establishments. Full-time housewives, religious leaders and persons without any stable income sources were also in the sample. Overall, the livelihoods of over $80 \%$ of the respondents hinged on informal casual economic activities. The present analysis is chiefly limited to data elicited from the Muslim participants who formed the bulk of the study sample.

\section{Beliefs about spousal contraceptive communication}

The women and men we studied were not disinclined towards contraceptive spousal discussion, and also did not express a lack of need for it. Rather, they frequently affirmed its importance, admitting that it could facilitate fulfilling marriages and promote spousal closeness and intimacy. Thirty-two-year-old Ramatu (a housewife) depicted spousal contraceptive communication as kafan $k^{\prime}$ 'auna, the foundation of love, while Hussain (a 45-yearold businessman) described it as key to a successful marriage. Indeed, their varying reproductive experiences notwithstanding, respondents eloquently stated that spousal contraceptive communication could facilitate the realisation of childbearing aspirations. They recognised its potential to prevent divorce, promote better childrearing, encourage positive couple engagement, and facilitate planning and co-operation in marriage. It also reportedly could facilitate better use of family resources and even 
prevent polygyny. Driving this point home, 37-year-old Abdalla notes: "it is good, if couples discuss together how to run their family and the number of children they can comfortably take care. This can help them avoid stretching themselves or having more children than they want".

Respondents who admitted to practising spousal contraceptive communication were also often more likely than those who did not to report limited or spaced childbearing. Thus, whether it occurred in polygynous or monogamous marriages, spousal communication on fertility was more commonly reported among spacers and limiters. Musa, a 52-year-old secondary school teacher, currently has eight children, four each from his two wives. He married his second wife 3 years after the first. Not wanting competition to lead them into unlimited childbearing, Musa said he discussed contraception both separately and jointly with both wives. As a teacher, he said he earned very poorly and only wanted about eight children. Based on their discussions, each wife was to have four children. A similar experience was reported by Saratu, a monogamously-married female respondent. She currently had four children and hopes to have the fifth (and final) child in the next 2 years. She and her husband, a successful businessman, agreed to have five children and to have an interval of 2 years between each birth. She recalls that her husband initiated the discussion right after the birth of their first son, saying: "I initially thought he wanted to marry another woman but he reassured me about it ...we agreed to have five children ... now it is easy to implement. He is the one who ensures that I have my contraceptives regularly. People here have many children because they do not discuss family size as husbands and wives".

\section{Constraints on spousal contraceptive communication} Men's narratives

The narratives we collated indicate that lack of spousal discussion on family planning was primarily driven by the ample incentives married men and women have to keep having children. Responding men frequently said they have not broached the matter of family planning with their wives because they did not want to make their wives suspicious or doubtful of their commitment to them. According to the men, remaining silent about contraception and family planning assures their wives of their love and commitment and a wife who is confident of a husband's love and commitment puts up little resistance when the (man) wants to marry other wives. In many instances, participating men felt that wives, rather than themselves, should bring up the matter of contraception. Bringing the subject up themselves could make wives doubt their dedication. "It is better, if they [women] bring it up themselves, if they really want it ... If it comes from me they would begin to nurture suspicions ...”, offered Rabiu, a 51-year-old polygynist.

Frequently, the men described family planning as women's business (maganan yanmata). By this they often meant two things: that women should decide whether or not to seek family planning and that women knew many reproductive secrets and could strategically deploy them without the knowledge of men. Sabo, a polygynist in his late forties, told us that family planning was women's issue because "even if you ask them to go for it, they will continue to give birth if they do not really want to stop ... they only stop when they want to. They are the ones who decide whether or not to stop...." Sabo admitted to his interest in discussing family planning with his wives, and said: "I don't want to have children that I can't train, so I would want to discuss it but you know, they will still do something else if they do not really want to follow my suggestion". Sabo, like most of the men we interviewed, recognised the importance of spousal communication on family planning. But like him too, they said they would not bring up the matter of family planning with their wives.

Men's narratives strongly revealed their awareness that wives use childbearing to safeguard their marriages, gain materially from husbands, and prevent men from seeking new wives. Asking one's wives to use contraception would hint at lack of love and make a wife suspect a husband's commitment to them. The Islamic juridical and cultural system supports fairness and equality in how husbands treat their wives. It obliges husbands to be impartial in their economic, sexual and social relationships with their wives. Responding men believed that bringing up the matter of fertility control with a wife could signal to her that the man was scheming to limit his support to her. It also could imply that the man is no longer inclined towards her, intends to marry another wife, and would favour the new wife more than her. Giving wives such impressions does not often augur well for men. Wives who doubt their husbands' love and commitment can divorce them and flee the marriage, leaving the man with several children; and bring their husbands into disrepute in the community.

However, men do not remain silent about contraception simply because it merely reassures their wives of their continued commitment to their union. Men suggested that remaining silent over family planning served strategic interests for them as well. By not bringing up the matter of family planning or demanding that their wives use contraception, men said they mollified their wives, ensured their continued stay within the household to care for any children, and prevented them from objecting to or protesting about their taking other wives. Refraining from bringing up the matter of contraception also guaranteed the loyalty of wives, demonstrating the men to be achievers and respected in the community. Men in one FGD noted that: "Here we do not show favouritism to a particular wife. The wife you tell to use family planning will bring trouble for you ... because she will feel you are planning something. She will run away and abandon several children for you". Men generally noted that aggrieved wives could make life difficult for their husbands. In Islamic northern Nigeria, women can easily manage to provoke a divorce. They can either goad their husbands into repeating the divorce formula or desert their marital homes. According to Wall, 22 a Muslim Hausa woman who is unable to provoke her husband to utter the divorce formula can also get one in a local Islamic court.

Our discussions with Malam Ali, a 40-year-old monogamist, showed that he was versed on the importance of, and held positive attitudes toward, family planning and spousal contraceptive discussion. Notwithstanding his conviction that discussing fertility and family planning with his wife would help them to agree on the number of children they can manage, Ali and his wife have yet to discuss family planning together. He admitted that he has yet to bring the matter up because he feels strongly that it may make his wife begin to feel he is no longer committed to the union. Said Ali: "If I tell her 'I think we should stop having children or I think we need to go for family planning', she would become suspicious. She may think I am tired of having children with her or that I want to marry a second wife". Ali claimed knowledge of several men whose wives fled their marriage, leaving behind several children because the men had suggested family planning to their wives. He also believes that his own wife may seek divorce if he mentions the importance of family planning to her, insisting that "it should come from her; because she is the woman ... it is better if wives bring up such things". 
Ali's experience bears much semblance to Hamid's. In common with many of the men we worked with, Hamid, husband to two wives and father of ten children, admitted that he has not raised the issue of family planning with either of his wives. He would have liked to discuss the issue of contraception with them, but he has refrained from doing so. Hamid is not keen on bringing up the matter of family planning with his wives because of the impression it might create with them. "It may cause them to think I am no longer able to cater for them and the children ... if you are the one encouraging or asking your wives to go to family planning, they will suspect your intention." In the longer narrative, Hamid explained that bringing up the issue of contraception with his wives could make them want to leave him. His situation is made more critical by his plans to take a third wife soon, which he says is important for his status as a ward head. While acknowledging that he does not need his wives' permission to marry a third wife, he also affirmed that he has to be careful with them as they can, out of dissatisfaction, behave in ways that could bring his name into disrepute in the community. Hamid strongly maintained that the best way to ensure that his wives do not act treacherously and disrespectfully is to not raise the subject of fertility control with them. This way, they would not seek divorce, disrespect him, or object to his taking another wife. They would know, he insisted, that he was still interested in supporting them whether or not a new wife arrives. Like Ali, Hamid admitted to a willingness to discuss contraception with his wives. But he also preferred his wives to be the first to moot the idea.

The narratives we elicited from Shehu, a relatively well-to-do husband with three wives and father of 19 children, provide further dimensions to the gendered interests that frustrate spousal contraceptive communication. Shehu admitted that he wanted many wives, but not many children. Polygyny, he told us, is a key status symbol. It marked men as achievers and respectable. Also, all his equally well-off peers have three or more wives. Shehu told us that his large family resulted largely from his hesitation to bring up the matter of family planning with his wives. He, however, also believes that bringing up the matter of fertility control with a wife could boomerang on the man. In the region, women, he noted, tend to doubt the devotion of husbands who tell them to limit their childbearing. Like Ali and Hamid, Shehu will not, himself, bring up the idea of family planning with his wives. He is, however, willing to support their uptake of family planning services should his wives bring it up.

\section{Women's narratives}

Much like the men, the women we studied were not averse toward discussing family planning with their husbands, and would not also broach it themselves. The women considered high parity to be key to the stability of their marriages. They believed that it could prevent one's husband from marrying another woman and sustain his attention and investment even when he does. ${ }^{23}$ Of course, they also openly admitted to using their reproductive capacity to gain economic and other advantages. To have many children, responding women said, was to insure one's marriage, sustain a husband's attention, and guarantee that one's household receives more of a husband's wealth. ${ }^{23}$ In the region, wives in polygynous marriages receive resources based on the number of children they have. The wife with the greatest number of children attracts the bulk of a husband's wealth daily and at his death.

The women we studied argued that men in the region use the excuse of wanting many children to marry many wives. In such situations, women had little incentive to use contraceptives or bring up the matter of family planning with their husbands. According to the women, limiting or spacing one's childbearing, though useful and achievable, could endanger a woman's marriage. Having many children and quickly too offered an effective strategy for dealing with the vicissitudes of marriage, including checkmating husbands by preventing them from marrying more wives, maltreating existing wives, or divorcing them. Said Kadijatu: "There is no need to tell him [one's husband] that you like to go for family planning; you will only end up helping him to marry another wife or you will be helping your co-wives... They will have all the children and take everything your husband has".

Women's narratives suggested that wives who open up with their husbands about their intentions to limit their childbearing risk a backlash. They would wreck their own socioeconomic and marital security. In their words, merely showing men love, being faithful to them, and even adoring them do not save a woman's marriage or guarantee the devotion of men. Whatever amount of love a wife shows a husband, he could still mistreat her, divorce her or marry new wives. Islam permits a man to marry up to four wives and to also divorce them at will. Pittin argues that under Islamic law, men have the right of unilateral divorce. ${ }^{24}$ Reportedly, only giving a man many children can guarantee the continued flow of his resources as well as his attention. Several children equate to receiving more of a man's resources. It also reduces the chances of mistreatment by the husband as a wife could decide to flee the marriage and leave him with many children. Against this background, women preferred high parity. ${ }^{23}$ Bringing up the issue of family planning reportedly communicated to husbands that one preferred a small family, which could encourage men to seek additional wives or even divorce existing ones. Women's narratives suggested that a new wife would also want to have her own children, rather than look after children from her husband's former marriage(s). Hajara said: "He can bring it up [family planning] and we will discuss it and I will want to know his intentions. If I bring it up, he may begin to have ideas. For men here, once a woman gives them the impression that she wants to have few children, they use it as an excuse to marry another wife or even divorce you". Hajara further suggested that most men would accept the idea of family planning if a wife brought it up; not because they have the interest of the woman at heart, but primarily because it would enable them marry more wives.

Hafsat (aged 46 years) aptly exemplifies how women's deployment of high parity in monogamous marriages prevented husbands from seeking other wives and also stifled spousal contraceptive communication. Married to Ahmed when she was 14 years old, they currently have eight living children. Ordinarily, admitted Hafsat, she would have only four children. But early on, she needed to stop Ahmed from marrying another wife. She is persuaded that her husband would have married another wife had she told him about her desire to have only four children. Hafsat concludes: "I know men here ... if you want to stop them from getting new wives, give them more responsibilities and don't talk about family planning. Fear of responsibility prevents them from marrying so many wives. When they remember that the responsibility for these children will only be theirs ... they rethink".

Conversely, Maimuna told us that she had to collude with her co-wife to prevent Suleiman, their husband, from marrying a third wife. They agreed not to broach the idea of family planning with him. They also agreed that one of them also had to get pregnant each year. Their husband is 
very wealthy, and limiting their childbearing would provide him with an excuse to seek additional wives. Maimuna asserts: "If we had four children each, it will be easy for him to marry a third or even fourth wife. He can even decide to throw you out of his house and then redistribute your children to the other wives, but now it is difficult for him to do this". Maimuna thinks they have been successful. She and her co-conspirator currently have seven children each and Suleiman has yet to marry a third wife.

Another interlocutor, Miriam, does not also consider it a particularly good idea to bring up the matter of family planning with Aliyu, her husband. Pregnant with her seventh child, she told us she married Aliyu when she was only 13 years old and that she would have liked to stop at four children. Her concern about the future and security of her marriage with Aliyu has, however, made this impossible. She says: "I know it is important to discuss how many children you want. But it won't be good for me. I would have liked to have only four children ... but then my co-wife already had four children and our husband who often says he likes children could also use it as an excuse to marry a third wife. So I figured that telling him about my intention to stop at four children will only hurt me. I have seen it happen to other women...”.

\section{Discussion and conclusions}

Decades of efforts to promote sustainable population growth in northern Nigeria notwithstanding, high fertility and low use of modern contraceptive methods still characterise the region. While poor spousal communication is often mentioned as a contributor to this situation, little research has probed the issues surrounding it in the region. Findings from the present study support extant evidence that the region's men and women are not completely disinclined toward spousal contraceptive discussion. ${ }^{7}$ The men and women we interviewed expressed awareness of the importance of spousal contraceptive communication, noting that it could help them implement their family size aspirations and better plan their childbearing. They also knew that it could facilitate marital fulfilment, support spousal closeness and intimacy, prevent divorce and polygyny, promote better childrearing, encourage positive couple engagement with each other, and facilitate planning and co-operation in marriage. However, the majority of them had never discussed family planning with their spouses.

In the present study, we observed a dynamic related to poor spousal contraceptive communication in the region that has been ignored in contemporary literature. This is that poor spousal communication in northern Nigeria is related to the broader context of gendered social identities and the micro-politics of marital relationships. It is motivated primarily by men's and women's tactical deployment of fertility to attain certain ends. Our data suggest that husbands and wives in the region have plenty of incentives to keep having children, and hence not to bring up the issue of contraception. For women, having many children seems to be a way to either prevent a man from marrying another woman or keep his attention and investment even when he does. ${ }^{23}$ By not asking them to limit their childbearing, men kept their wives from objecting to their taking additional wives and assured them continued commitment should they marry additional wives. Not initiating contraceptive communication, even when they actually recognise its importance, serves very concrete functions to men and women in northern Nigeria. It is strategic to their realisation of some critical interests.

Having several children was for the women strategic to preserving their marriages, preventing their husband from marrying additional wives, and retaining his attention and investment even when they do. For the women we studied, having many children is a powerful strategy; one that, in their view, gives them more leverage with both co-wives and husbands. 23

Our findings challenge conventional population, family planning and reproductive health programmes that tend to view high fertility as disempowering for women, and contraceptive use as capable of redressing gender inequality. Married women's use of high parity as a microtactic for economic survival has been noted in the literature. In the face of widespread norms and practices of gendered economic relationships that altogether limit women's economic mobility and independence, the basis of contemporary northern Nigerian women's social and material survival is the strategic deployment of their reproductive prospects. ${ }^{11,23,25-27}$ In northern Nigeria, the lives of women are generally characterised by poverty, hardship and dependence on men. While a number of northern Nigerian women engage in income-generating activities, a large number of them currently spend their lives in seclusion (purdah) relying, for the most part, on their husbands for sustenance. ${ }^{28}$ Often, their economic well-being and survival in these unions depend on the strategic use of their fertility. In this context, they have ample incentives not to raise the matter of family planning with their husbands, but rather to keep having children. The women we studied depicted having many children as key to securing their marriage, guaranteeing the support and attention of their husbands in the long run, and dealing with poor socioeconomic and livelihood conditions. ${ }^{23}$

For men, having more children helps them to keep their wives from objecting to their taking other wives, and to mollify them by showing their continued commitment to that relationship should they take other wives. Remaining silent about family planning, even when they actually wish for it, thus served very concrete functions for the men. Cornwall $^{9}$ notes that reproductive outcomes are not always consciously pursued; they can result from the everyday realities with which individuals contend. Men in the present study preferred to remain silent about contraception in order to effectively manage the circumstances needed to prove their commitment to their wives, elicit their loyalty, mollify them, guarantee their continued stay within the household to care for any children, and ensure that they do not object to nor protest at their taking other wives. Refraining from bringing up the matter of contraception also helped husbands to ultimately validate themselves as achievers and being considered respectable in the community.

Overall, poor spousal contraceptive communication - a key driver of high fertility in northern Nigeria - is, by and large, the by-product of the incentives and disincentives that men and women have within marital unions in which fertility is a crucial factor, as also is the experience of living in a context in which dominant discourses hardly openly support limited fertility. The evidence also suggests that women's dependence on men for economic survival results in apprehension about bringing up the matter of family planning. It is also largely evident that men are hesitant to bring up the matter of family planning with their wives because of their need to ensure that their wives do not object to or protest at their taking other wives, which shows the men to be, amongst other things, achievers and respectable men.

On closer inspection, it is also evident that underlying the high fertility-producing strategies of the northern Nigerian men and women we studied is a form of unmet need for contraception. Respondents in the study 
continually expressed a basic desire for lower fertility. Many of them were aware of the virtues of smaller families, with several women stating that they would seek contraception surreptitiously and men also commenting that they were desirous of smaller families. Taken together, the evidence presented here is critical for social and policy action aimed at improving the uptake of family planning in northern Nigeria. It suggests the key influence of gender norms and economic inequities between men and women on fertility behaviour in northern Nigeria. To deliver their expected impacts, efforts to support women's access to contraception in northern Nigeria need to be matched by the creation of new social norms of gender relations and economic opportunities. ${ }^{11}$

Statements on funding and competing interests

Funding This study was funded by The Packard Foundation (Grant No. 2007-31851).

Competing interests Mairo Mandara works for The Packard Foundation, the funders of the study.

\section{Acknowledgements}

The authors are grateful to The Packard Foundation for financial support and to their fieldworkers and respondents for the data used in the study.

\section{References}

1 National Population Commission (NPC) Nigeria \& ORC Macro Nigeria Demographic and Health Survey 2003. Calverton, MD: NPC ORC Macro, 2004.

2 African Population and Health Research Center (APHRC). Unmet Need for Contraception in Nigeria: A Focus on Packard Foundation Program States. Report submitted to the Packard Foundation, Nigeria Office. Nairobi, Kenya: APHRC, .2007.

3 Izugbara C, Ezeh A, Ibisomi L, Mberu B. Change and Continuity in Reproductive Norms and Behaviour: A Northern Nigeria Study. Nairobi, Kenya: African Population and Health Research Center (APHRC), 2009.

4 Packard Foundation. Nigeria: Country Report, 2007. http://www.packard.org/assets/files/population/program [Accessed 12 November 2008].

5 Isiugo-Abanihe UC. Male Role and Responsibility in Fertility and Reproductive Health in Nigeria. Ibadan, Nigeria: Center for Population Activities and Education for Development, 2003.

6 Rakhshani F, Niknami S, Moghaddam AA. Couple communication in family planning decision-making in Zahedan, Islamic Republic of Iran. East Mediterr Health J 2005; 11: 586-593.

7 Kabir M, lliyasu Z, Abubakar IS, Maje BS. The role of men in contraceptive decision making in Fanshekara village, Northern Nigeria. Trop J Obstet Gynaecol 2003; 20: 24-27.

8 Duze MC, Mohammed IZ. Male knowledge, attitudes, and family planning practices in Northern Nigeria. Afr $J$ Reprod Health 2006; 10: 53-65.

9 Cornwall A. Taking chances, making choices: the tactical dimensions of "reproductive strategies" in southwestern Nigeria. Med Anthropol 2007; 26: 229-254.

10 Rapp R, Ginsburg F. The politics of reproduction. Annu Rev Anthropol 1991; 20: 311-343.

11 Foley EE. Overlaps and disconnects in reproductive health care: global policies, national programs, and the micropolitics of fertility and contraceptive use in northern Senegal. Med Anthropol 2007; 26: 323-354.

12 Greenhalgh S. Toward a Political Economy of Fertility: Anthropological Contributions (Population Council Research Division Working Paper No. 12). New York, NY: Population Council, Research Division, 1990.

13 Browner C, Purdue ST. Women's secrets: bases for reproductive and social autonomy in a Mexican community. Am Ethnol 1988; 15: 84-97.

14 Browner $C$. The politics of reproduction in a Mexican village. Signs 1986; 11: 710-724.

15 Smith DJ. Legacies of Biafra: marriage, 'home people' and reproduction among the Igbo of Nigeria. Africa 2005; 75: 30-45.

16 Izugbara CO, Ezeh AC, Otsola K. Men, women and abortion in Central Kenya: a study of lay narratives. Med Anthropol 2009; 28: 397-425.

17 Rhine K. Support groups, marriage, and the management of ambiguity among HIV-positive women in northern Nigeria. Anthropol Q 2009; 82: 369-400.
18 Burnard PA. Method for analyzing interview transcription in qualitative research. Nurse Educ Today 1991; 11: 461-466.

19 Dobrzykowski TM, Stern PN. Out of sync: a generation of firsttime mothers over 30. Health Care Women Int 2003; 24: 242-254.

20 George A. Differential perspectives of men and women in Mumbai, India on sexual relations and negotiations within marriage. Reprod Health Matters 1998; 6: 87-96.

21 Population Council. Child Marriage Briefing. Abuja, Nigeria: Population Council, 2005.

22 Wall L. Dead mothers and injured wives: the social context of maternal morbidity and mortality among the Hausa of Northern Nigeria. Stud Fam Plann 1998; 29: 341-359.

23 Izugbara CO, Ezeh AC. Women and high fertility in Islamic northern Nigeria. Stud Fam Plann 2010; 41: 193-204.

24 Pittin RI. Women and Work in Northern Nigeria: Transcending Boundaries. Basingstoke, UK: Palgrave/Macmillan, 2002.

25 Foley EE. In sickness and in health. Responding to disease and promoting health in Senegal. PhD dissertation, Michigan State University, East Lansing, MI, USA, 2001.

26 Carter A. Agency and fertility: for ethnography of practices. In Greenhalgh S (ed.), Situating Fertility: Anthropological and Demographic Inquiry. Cambridge, UK: Cambridge University Press, 1995; 55-85.

27 Lopez 1O. Agency and constraints: sterilization and reproductive freedom among Puerto Rican women in New York City: Urban Anthropology and Studies of Cultural Systems 1993; 22(3/4): 299

28 Yusuf M. The status of women in contemporary Kano. Nation, 2 July 2008.

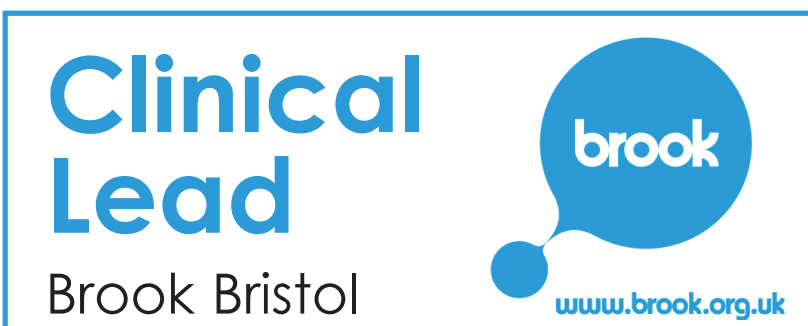

Brook Bristol is an exciting and innovative sexual health service providing care for young people under the age of 25 in a central clinic and a variety of outreach settings.

The post is for 12 hours ( 3 sessions) per week divided into 6 hours direct clinical care and 6 hours administration.

The post holder will play a crucial role in the service. They will be expected to provide young people with expert contraception and sexual health information and advice. They will also advise the Chief Executive and Trust Board on areas including clinical governance, best practice and service developments and take a lead in the delivery of teaching and training to clinical staff.

For a copy of the job description and application pack please contact

Sue Simpson on

ssimpson@brookbristol.co.uk

or Annie Vanbeck on

avanbeck@brookbristol.co.uk Tel: 01179225999

Deadline for applications 31st October 2010. 